\title{
A REPRESENTAÇÃO DOS CIGANOS EM CONTOS DE JORGE MEDAUAR
}

\author{
Luana Isabel Silva de Assis* \\ Cristiano Augusto da Silva Jutgla
}

RESUMO: O artigo apresenta uma análise sobre a representação dos ciganos nos contos "O cigano" e "A volta do cigano", publicados pela primeira vez no livro A procissão e os porcos (1960), do escritor sul-baiano Jorge Medauar. Assim, discutimos como o escritor destaca a presença dos povos ciganos no interior do sul da Bahia, além de abordarmos os aspectos de sua narrativa e questões de alteridade.

PALAVRAS-CHAVE: Alteridade; Ciganos; Jorge Medauar; Literatura regional.

Jorge Emilio Medauar, filho de imigrantes árabes, nasceu em 1918 no povoado de Água Preta do Mucambo, atualmente município de Uruçuca, na região sul da Bahia. Ainda jovem mudou-se para São Simão, interior de São Paulo com seus pais, Emilio Medauar e Maria Zaidan Medauar. Sua carreira se inicia no Rio de Janeiro no ano de 1945, a partir deste período trabalhou em duas revistas ligadas ao Partido Comunista Brasileiro (PCB), como secretário na Literatura ${ }^{1}$ (1946-1948) e redator na Fundamentos (1948-1955).

\footnotetext{
* Mestranda no Programa de Pós-Graduação em Letras: Linguagens e Representações da Universidade Estadual de Santa Cruz (Uesc). Bolsita da Fundação de Amparo à Pesquisa do Estado da Bahia (Fapesb)

** Doutor em Literatura Brasileira pela Universidade de São Paulo. Professor Titular da Universidade Estadual de Santa Cruz (Uesc) e Professor permanente do programa de Pós-Graduação em Letras: Linguagens e Representações (Uesc).

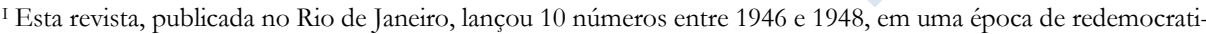
zação no Brasil, tinha como objetivos versar sobre a literatura nacional e estrangeira, mas também manifestar posicionamentos políticos. Foi dirigida por Astrogildo Pereira, um dos fundadores do Partido Comunista Brasileiro, por isso o caráter militante da revista e dos intelectuais que estavam envolvidos em sua produção: Álvaro Moreira, Aníbal Machado, Arthur Ramos, Manuel Bandeira, Graciliano Ramos, Orígenes Lessa, Antonio Ferreira 
Nesse momento, o Brasil estava em um período de democracia após a ditadura do Estado Novo capitaneada por Getúlio Vargas. Mas com o golpe de 64 e a implementação do regime militar foi cessado novamente o direito ao estado democrático e à liberdade de expressão. Por conta de sua militância, Jorge Medauar foi preso e recebeu ameaças em ambos os períodos de ditadura.

Ele se consolidou como jornalista e publicitário em São Paulo. Enquanto escrevia contos e poemas, atuou em faculdades, jornais, revistas e agências de publicidade. Fundou a Escola Superior de Propaganda e Marketing de São Paulo (ESPM) e exerceu na instituição as funções de diretor e professor. Foi secretário, diretor, colaborador, assessor, entre outras funções, de diversos jornais como O Estado de São Paulo, A Tarde (Salvador) e O Globo. Como escritor representou a UBE (União Brasileira de Escritores) no Rio de Janeiro e São Paulo e foi membro das academias de Letras de Ilhéus e Brasileira de Literatura Infantil e Juvenil de São Paulo (ODETE, 2006).

De amplas relações nos meios artísticos e intelectuais, conviveu com nomes da literatura como Manuel Bandeira, Guimarães Rosa, João Cabral de Melo Neto, Carlos Drummond de Andrade, Graciliano Ramos e o seu conterrâneo Jorge Amado. De sua extensa produção literária, podemos delinear sua obra em dois grupos; o primeiro, composto de livros de poemas: Chuva sobre a tua semente (1945), Morada de paz. (1949), Prelúdios noturnos e tema de amor (1954); Fluxograma (1959) e Jogo chinês (1962), e um exclusivamente de sonetos, À estrela e aos bichos (1956). O segundo conjunto é formado por contos: Água Preta (1958), prêmio Jabuti da Câmara Brasileira do Livro; 2 contos de festas, com Ricardo Ramos (1958); A procissão e os porcos (1960); Histórias de menino (1962); O incêndio (1963), prêmio Governador do Estado de São Paulo; Jorge Medauar conta estórias de Água Preta (1975); No dia em que os peixes pescaram os homens (1978); Bom como diabo (1982); Visgo da terra (1983); Contos encantados

da Silva e Jorge Medauar. A revista contava com colaboradores como Carlos Drummond de Andrade, Lúcia Miguel-Pereira, Jorge Amado, Francisco de Assis Barbosa, entre outros (MELO, 2015). 
(1985); Viventes de Água Preta (1996). Há também um livro de ensaios lançado pela Editus, editora da Universidade Estadual de Santa Cruz: Ensaios (2000).

Seus contos e poesias receberam traduções diversas e estão presentes em antologias brasileiras e estrangeiras: Panorama do conto baiano (1959); Coleção Imbondeiro (1963), publicada em Angola; O moderno conto da região do cacau (1978); Cacau em prosa e verso (1982). Jorge Medauar faleceu em São Paulo no dia 3 de junho de $2003^{2}$.

$\mathrm{Na}$ abordagem sobre a obra de Jorge Medauar é importante discutir a ideia de regionalismo para compreender o contexto de sua produção literária, pois os seus contos possuem temas, ambientes e personagens do interior baiano. Segundo Ligia Chiappini (2013), o regionalismo brasileiro já foi considerado como ultrapassado por alguns críticos, de modo que não existiriam justificativas para pesquisas acerca desse tipo de produção após a década de 30. Entretanto, a autora, analisa também a visão de Antonio Candido, o qual considera a necessidade de se prosseguir com investigações sobre o assunto, pois, como as demais correntes literárias, o regionalismo é histórico e passa por processos de transformação.

Para Walnice Galvão (2000) o “primeiro regionalismo”, um subproduto do romantismo e também chamado de sertanismo, surgiu na primeira metade do século XIX após críticas e reinvindicações da falta de representatividade do interior brasileiro. O pitoresco, a descrição de animais, frutas, nomes inusitados, a cor local e os tipos humanos eram o interesse e a inspiração para as produções nesta fase.

Um "segundo regionalismo" manifesta-se na segunda metade do século XIX sob as influências do naturalismo, uma vez que apresenta visões contrárias às do romantismo; por assim dizer, essa tendência apresenta descrições mais racionais, com a atenção voltada

\footnotetext{
II Os livros Jorge Medauar em prosa e verso (2006), organizado pela família do escritor e lançado pela Editus e Jorge Medauar, o bomem que sabia demais (2008), organizado por seu amigo e colega de trabalho Emanuel Pimenta, fornecem mais informações sobre a vida e obra de Medauar através de memórias, cartas, depoimentos, pessoas com quem o escritor se relacionou bem como materiais acerca de seus livros de poesia e prosa.
} 
para a ciência, determinismo, pessimismo, fatalismo, como fatores aos quais o homem estava exposto e que influenciavam sua vida. Nas duas fases os escritores se empenharam em expor a diversidade de paisagens, das condições sociais e dos tipos humanos do interior do país como: o caipira, o jagunço, o retirante, o caboclo, o tropeiro, etc.

Galvão (2000) afirma que ressurgiu um “terceiro regionalismo” após o modernismo dos anos 20. O regionalismo de 30 foi inspirado pelo romance social norte-americano e por uma espécie de neonaturalismo interessado em denunciar as injustiças, desigualdades e preconceitos. Assim, as artes e a literatura manifestaram a sua forma de resistência à ascensão dos totalitarismos e dos regimes de exceção no período em que ocorreram as duas grandes guerras mundiais.

No Brasil, o regionalismo de 30 se tornou a vertente dominante na prosa brasileira, com o romance como gênero principal, mais apurado que os regionalismos anteriores, as vertentes nordestina e sulista apresentaram temas ligados ao interior brasileiro. A geração de 30 teve como destaque José Lins do Rego, Graciliano Ramos, Jorge Amado, Érico Verissimo, Dionélio Machado, entre outros.

Ao mesmo tempo, no cenário brasileiro, ocorria uma reação espiritualista de outra tendência literária que não possuía relação com as concepções regionalistas, o posicionamento político e atenção para questões sociais, o acirramento ideológico era intenso durante a década de 1930/1940. Boa parte dos escritores tinha posições claras, ou à esquerda ou à direita. O romance introspectivo penetra na subjetividade e demonstra afinidade com a romance católico francês do entre guerras, essas obras tinham as discussões voltadas para os problemas urbanos, decadência e degradação moral do indivíduo.

Os escritores que seguiram essa abordagem trabalharam a introspecção, a reinvindicação de uma espiritualidade perdida, a perdição da alma, para eles, é muito mais grave ao homem em comparação com as perdas materiais. Os autores manifestam aversão à cor local, ao pitoresco, ao fato dos regionalistas falarem em religião apenas como forma de crítica (GALVÃO, 2000). 
Para a pesquisadora, existia um panorama literário ramificado, com isso alguns escritores apresentam um entrecruzamento do regionalismo e da reação espiritualista. Consideramos Jorge Medauar como um dos escritores brasileiros de ficção que atuam entre as duas vertentes, apresentando um regionalismo com características introspectivas.

Analisar obras individualmente significa aprofundar e respeitar suas singularidades, fato que não costuma ocorrer quando elas são postas em conjunto focadas sob uma perspectiva de tendências gerais, prática recorrente nos grandes esquemas das histórias literárias, as quais consideram que todas as produções do regionalismo possuem as características semelhantes e/ou são construídas da mesma forma, contribuindo para esquemas interpretativos que as caracterizam como limitadas do ponto de vista estético e ideológico. Por essa razão, o presente artigo sobre contos de Jorge Medauar contribui para essa necessidade de desenvolvimento de estudos monográficos no âmbito do regionalismo literário.

Nas suas obras em prosa, o escritor, inserido na literatura brasileira moderna de 45, aborda as questões do homem, do cotidiano em geral, focaliza na realidade do nordeste brasileiro, a região cacaueira do sul da Bahia, explora a psicologia dos personagens e as suas relações com o mundo. Nosso objetivo é analisar os contos "O cigano" e "A volta do cigano", mais especificamente, a forma como Jorge Medauar representa a presença desses povos no sul da Bahia e as relações com os não-ciganos.

Jorge Medauar não se coaduna com a representação das relações de poder da região sul baiana, por isso a saga do cacau, as disputas por terras entre os coronéis e as guerras sangrentas de família não são elementos centrais de seus contos; tais questões vêm em segundo plano, pois sua intenção é narrar a vida de pessoas dos grupos sociais menos favorecidos economicamente, não como ignorantes ou subalternos, mas como personagens complexos, detentores de experiência e sabedoria. 


\section{"O cigano" e "A volta do cigano"}

O conto trata de um cigano ambulante que, além de vender seus produtos nas feiras das pequenas cidades, narra histórias que encantam seus clientes. No início, o texto evidencia que o personagem apreciava a leitura, pois não a interrompia por qualquer distração, apenas quando identificava um bom comprador:

Suas histórias atiçavam o juízo. Como podia ser que uma pessoa amontasse numa esteira - ficavam se perguntando os roceiros - e saísse avoando pelas nuvens, de um canto para outro? Os caititus não sabiam como diabo podia haver uma esteira, um tapete mágico que flutuasse nas alturas, sustentando gente. Voltavam para o cacau com a cabeça fervendo, zunindo feito caixa de marimbondo. Muitas vezes ficavam pela noite reunidos, judiando com o miolo, procurando enfiar no entendimento a história de um rei amasiado com mais de trezentas mulheres, todas socadas na mesma casa, dançando só para ele se regalar. O cigano falava em sultão e sultão para eles era nome de cachorro. O homem dizia coisas que pareciam invenção da cabeça [...]. Afinal suas histórias ajudavam a esquecer o eito duro do cacau, o suor de muitos dias pingando debaixo de sol, a mão engrossando no cabo do facão, na enxada que ia e vinha, trazendo o sustento sofrido de todos os dias (MEDAUAR, 1960, p.8384).

As histórias eram momentos de fruição e as pessoas não deixavam de pensar e questionar como era possível acontecer os fatos narrados. Os "tabaréus" conheciam muitas histórias, mas as do cigano eram diferentes, ele andou por muitas terras e podia presenteálos com novidades, principalmente com aqueles casos em que os heróis faziam justiça por pessoas pobres e humildes. Decerto os trabalhadores do cacau tinham a esperança de alguém fazer algo por eles, pois viviam no sistema em que os patrões apenas visavam o próprio enriquecimento e não se preocupavam na qualidade de vida para seus empregados.

A importância das histórias para seus compradores, geralmente pessoas pobres e de pouca instrução formal guarda contato com as reflexões de Candido (1995) quando este discute a necessidade do acesso à literatura na vida e formação dos seres humanos, considerando como tal todas as criações com traços poéticos, ficcionais ou dramáticos de todos os níveis sociais e culturais: 
Vista deste modo a literatura aparece claramente como manifestação universal de todos os homens em todos os tempos. Não há povo e não há homem que possa viver sem ela, isto é, sem a possibilidade de entrar em contato com alguma espécie de fabulação. Assim como todos sonham todas as noites, ninguém é capaz de passar as vinte e quatro horas do dia sem alguns momentos de entrega ao universo fabulado. O sonho assegura durante o sono a presença indispensável deste universo, independente da nossa vontade. E durante a vigília a criação ficcional ou poética, que é a mola da literatura em todos os seus níveis e modalidades, está presente em cada um de nós, analfabeto ou erudito -, como anedota, causo, história em quadrinho, noticiário policial, canção popular, moda de viola, samba carnavalesco. Ela se manifesta desde o devaneio amoroso ou econômico no ônibus até a atenção fixada na novela de televisão ou na leitura seguida de um romance (CANDIDO, 1995, p. 242).

As histórias contadas pelo cigano despertavam o interesse nas pessoas justamente por esta necessidade do devaneio, do sonho. Se não era acessível por outros meios, o cigano cumpria a função de alimentá-los de ficção, em contrapartida a garantia de sua subsistência estava na venda acompanhada de histórias, por isso ele despertava a curiosidade das pessoas, pois elas retornavam em busca de novos casos, desfazer dúvidas dos antigos, e, consequentemente compras mais produtos.

Os fazendeiros gostavam do cigano, pois ele indiretamente os servia e proporcionava alguns benefícios, como a distração para os trabalhadores, vendia coisas que só poderiam ser encontradas na cidade, e, ainda, acreditavam que ele trouxe para a cidade a sorte de uma safra. Os donos das lojas ficavam admirados com o seu desempenho na feira, assim um dos comerciantes de Água Preta, João das Neves, decide oferecer-lhe uma proposta de trabalho:

Mas quando foi contratar o serviço, o cigano, na frente de todo mundo, só fez balançar a cabeça e ficar sorrindo: não havia dinheiro no mundo que armasse seus pés num lugar, disse. Queria montar seu animal, armar sua tenda em qualquer canto. Onde estivesse, comeria. Onde chegasse, aí dormia. Gostava era de bater estrada, vendo os matos, ouvindo os bichos, o canto dos passarinhos. Perguntou depois a seu João quanto valia beber água na concha da mão, na beira de um riacho de água fresca, no caminho de uma viagem. Seu João se espantou, arregalou os olhos. O diabo do cigano tinha 
a cabeça mole. Danou-se, quando viu que o homem estava era com mangação grossa. Sentiu-se derrotado. Então saiu dizendo por aí a fora que o cigano era pancada. Espalhou a história debaixo de zombarias, entortando o caso a seu modo. O cigano havia sumido. Noutra viagem a Água Preta, o povo se lembrou, arrodeou o homem com perguntas. Queriam saber como alguém podia desprezar um emprego daqueles, trocar cama com lençol por uma esteira estendida nos capins dos matos, arriscado a ser mordido de cobra. Só mesmo profeta. Pelo sertão havia muito vidente que não trocava nada desse mundo com as riquezas dos homens. [...]. Nessa hora o coronel Afrânio ia passando, a mão arriada com o peso do seu anel de brilhante, quase do tamanho de um limão. [...]. Encontraram um caminho para perguntar ao cigano sobre o anel. E se lhe dessem aquela pedra? Respondeu que não trocaria uma goiaba pelo anelão. A resposta valia para confirmar tudo que seu João das Neves espalhava: o homem andava mesmo de juízo frouxo, os miolos balançando. Homem que não ambicionasse nada, que não parasse um bom pedaço de tempo no mesmo lugar não servia não (MEDAUAR, 1960, p.85-86).

O comerciante invejoso, deseja ter o homem como seu empregado, pois com ele lucraria mais que qualquer outro da cidade. O fato do cigano ser bem-sucedido com suas vendas causava inveja em João das Neves, como obteve uma resposta negativa passa a odiar o cigano e proibir seu filho de ir para tenda escutar as histórias. Por causa das ofensas que o comerciante espalhava pela cidade, o cigano ficou por um período afastado de Água Preta, com o seu retorno João das Neves teme por uma possível vingança, pois a sua mente também estava contaminada pelas mentiras que inventou.

Neste segundo momento do texto, o cigano demonstra a sua emoção em pensar que não poderá mais contar histórias para os meninos e sofria por não poder evitar a repressão do João da Neves com o filho. Por fim, o comerciante consegue expulsá-lo da cidade contratando um grupo de cegos cantadores, que conseguem atrair a atenção de todos os frequentadores da tenda do cigano.

A obra reflete a militância política de Jorge Medauar, por exemplo, em algumas passagens do conto "O cigano", há alusões ao problema da posse da terra e ao direito à propriedade, um dos pilares do capitalismo. Isso acontece quando o personagem fala para as pessoas que o mundo e tudo que existia, terras, animais, frutas, não deveriam possuir 
donos. Todas as coisas deveriam estar disponíveis para as pessoas usufruírem, pois, a ambição tomou conta de tudo e prejudica a convivência entre as pessoas. Assim, o conto apresenta uma crítica ao sistema capitalista e os aspectos negativos que ele causa nas relações sociais.

Em "A volta do cigano" ocorre uma reviravolta na história. O filho de João das Neves está doente e em seus delírios febris chama pelo cigano, isso ocorre porque o homem tinha uma relação especial com as crianças, ficava feliz de saber que gostavam dele e o esperavam. O comerciante lamenta o castigo recebido, está preocupado com o sofrimento da mulher, pois o menino não reage com nenhum tratamento. Foram utilizados medicamentos tradicionais, chás, rezas, candomblezeira, aspectos presentes no texto que apontam a importância da religiosidade e da cultura popular para as pessoas da região.

No conto ocorre a "redenção" do cigano, que será enxergado por todos os moradores de Água Preta, como uma pessoa sábia, que retorna à cidade para salvar um menino. A chegada do cigano era muito aguardada, por isso o narrador questiona quem não desejaria ver a quantidade de pessoas agrupadas na porta de João das Neves e não se emocionaria com o encontro do homem com os pais do menino, a fim de enfatizar a importância da cena.

"A volta do cigano" é um conto que estende a narrativa e apresenta outro desfecho para o primeiro conto. É uma prática utilizada pelo escritor em outros contos, por vezes um personagem, cujo desfecho de sua trajetória ficara em aberto, será desenvolvido em outra história; assim, o leitor, que leu os outros contos, faz a ligação entre as narrativas. Compreendemos que essa técnica é utilizada para mostrar ao leitor que todas as histórias e personagens estão interligados, afinal o espaço ficcional é uma pequena cidade do interior, onde a maioria das pessoas se conhecem e possuem um convívio mais próximo.

Observamos que a narração ocorre por intermédio tanto de um narrador e, também, das falas e pensamentos dos personagens, no entanto este narrador onisciente neutro, que se interpõe entre o leitor e a história, não é o autor, pois na construção do conto exis- 
tem traços indicativos do seu distanciamento. A linguagem é coloquial e em nenhum momento é demarcada a linguagem de um autor ou narrador que possui uma linguagem diferente dos personagens, outro fato é que não existe um posicionamento, opinião sobre os acontecimentos no texto, sempre que ocorre um posicionamento contra ou a favor de algum fato, ele surge através da fala de algum personagem.

Em relação aos pontos de vista da história Norman Friedman (2012) propõe que podem ocorrer de diversas formas. Com o autor onisciente intruso, o narrador expõe suas palavras, pensamentos e percepções. No caso do onisciente neutro, não existem instruções e comentários. A presença do narrador entre o leitor e a história fica clara, esta parece contar-se a si mesma, e o escritor revela através dos personagens o que lhe interessa, com predominância do narrador descrevendo e explicando ao leitor com sua própria voz. [

Friedman (2012) discutiu a questão do desaparecimento do autor no texto ficcional e como o ponto de vista oferece modos de operação para compreensão das possibilidades de extinção autoral na narrativa:

Se a "verdade" artística é uma questão de compelir a expressão, de criar a ilusão da realidade, então um autor que fale em sua própria pessoa sobre a vida e fortunas de outros estará colocando um obstáculo a mais entre a sua ilusão e o leitor, em virtude de sua própria presença. Para remover esse obstáculo, o autor pode optar por limitar as funções de sua própria voz pessoal de uma maneira ou outra (FRIEDMAN, 2012, p.169).

O distanciamento do autor é uma das formas de criar a noção de realidade para o leitor. Um dos meios para limitar a presença autoral é contar a história por meio da terceira pessoa. Desta forma, a ação é acompanhada pelo leitor ao mesmo tempo em que se efetua na mente do personagem.

Friedman (2012) afirma que os estudos de Beach, em 1932, sobre a técnica do romance do século XX, apontam como uma das características principais o fato de a história prestar contas a si mesma, o autor não emite opinião ou incita o leitor a fazê-lo. Ele deixa que os personagens falem, expressem o que sentem e como processam as situações em 
suas mentes. Se o problema do narrador é a forma mais adequada para transmitir a história ao leitor, Friedman (2012) destaca que se deve pensar em quem fala ao leitor, qual posição esta pessoa ocupa em relação à história, os canais de informação utilizados e a que distância o leitor é colocado.

Dos modos de transmissão da história, Friedman (2012) fala sobre a diferença entre o sumário narrativo (contar) e da cena imediata (mostrar). No caso do sumário os eventos são informados em uma extensão de tempo e com variedade de locais, ele considera como o modo simples de narrar. Com a cena, existe a apresentação de detalhes específicos, contínuos e sucessivos de tempo, espaço, ação, personagem e diálogo surgem em uma estrutura específica de tempo e espaço. Na ficção moderna as obras focam mais na cena e na tradicional no sumário narrativo.

Quando a narrativa passou a apresentar a onisciência seletiva múltipla, a história passou a ser contada diretamente através da mente das personagens e de suas impressões. A onisciência seletiva ocorre da mesma forma que a anterior, porém um indivíduo terá suas ocorrências mentais como centro da narrativa. Neste tipo de narração existe um predomínio da cena:

Um duro castigo de Deus. Agora tinha que encontrar o homem, mandar bater estradas, varejar cidades e povoados. Por onde andaria o cigano, Senhor? Sentia vontade de morder os pulsos, arrumar a testa nas paredes. Tinha que dar o braço a torcer, dobrar o cangote, Humilhar-se. Antes não tivesse feito judiaria, não tivesse comandado a pagodeira dos cegos, uns inocentes que não podiam ver o que faziam (MEDAUAR, 1960, p. 124).

Neste caso, a situação é narrada por via do pensamento de João das Neves, o personagem acredita que foi castigo por Deus ao cometer um mal ao outro. Assim, deve se submeter ao cigano, mesmo contra a sua vontade. No entanto, analisamos que arrependimento neste momento não é pelos prejuízos causados a outra pessoa, mas pelo fato de ter o trabalho de encontrar o cigano e necessitar dele para salvar seu filho. 
Podemos dizer que Medauar não segue um modelo tradicional adotado por muitas obras regionalistas, pois ele não apresenta narradores ou personagens correspondentes no todo ou parcialmente aos valores patriarcais, portanto elevam a figura do homem branco, de classe média ou alta, detentor de poder. Para Ginzburg (2012, p.200), este modelo tradicional é constante na ficção do século XIX e XX, sobretudo, em textos regionalistas, romances históricos e sagas familiares, ao utilizarem dos valores da cultura patriarcal como referência para definição de comportamentos e moralidades.

O autor ainda salienta sobre os novos panoramas da produção literária brasileira contemporânea, compreendida dos anos 60 para cá, contrastantes com os modelos seguidores dos valores canônicos. São necessárias novas perspectivas de análise e interpretação para a diversidade de configurações, vocabulários e temas que não se enquadram em uma determinada periodização convencional. É justamente nesse período o início das publicações dos contos de Medauar até os anos 90.

A história dos ciganos é composta por lendas e diversas suposições quanto as possíveis origens. Para Coutinho (2013, p. 26), a cultura cigana é marcada pela tradição oral, por esse motivo, não foram produzidos documentos escritos que possibilitem uma investigação histórica a partir de relatos dos próprios ciganos. No entanto, o fato de que não existia espaço para a voz dos marginalizados é o principal motivo para que os documentos apresentem a sua história a partir da perspectiva do outro, no caso, aqueles que detinham o poder.

A maioria dos dados se encontravam em inquéritos, processos, relatórios polícias e notícias de jornais que apontavam a imagem dos ciganos na sociedade. Nestes documentos também estavam presentes as políticas que foram implementadas para controlar a permanência nas cidades e estados.

De acordo com Borges (2007, p.18), as lendas que justificavam o nomadismo cigano relatam que eles passaram a viver sem um lugar fixo, pois foram condenados por terem um dia negado a fé cristã ou por serem descendentes de egípcios que recusaram hospitalidade 
à sagrada família no momento do nascimento de Jesus. Mas essa prática pode ter sido iniciada por conta de motivações diversas e que geraram migrações de diversos grupos por todo mundo.

A pesquisadora afirma que a marginalização dos ciganos está relacionada com a chegada da Era moderna e a crescente valorização do trabalho. Eles eram considerados como inúteis por não se adequarem ao sistema que preconizava o trabalho assalariado e a disciplina. Leis e decretos asseguravam a expulsão das cidades, multas, confisco de bens e violência por meio da extirpação de órgãos do corpo, trabalho forçado e pena de morte, com enforcamento para os homens e afogamento para as mulheres.

Jean-Claude Schmitt (1998), em sua definição do que é um marginal, explica que existe uma marginalidade consciente e contestatária formada por grupos que eram contra o sistema capitalista, o tradicionalismo, a ética do trabalho e outras questões. Outros tipos de marginalidade ou de exclusão menos provocadoras e não voluntárias, na visão do autor, são mais importantes, pois demonstram as injustiças sociais que são inerentes ao funcionamento das sociedades.

De acordo com Schmitt (1998, p. 275-6), os ciganos, assim como outros grupos marginalizados, eram considerados como falsos pobres ou "mendigos válidos", ou seja, podiam trabalhar e não o faziam. $\mathrm{O}$ trabalho tinha um valor ético que era imposto pelas autoridades e pela literatura que falava sobre mendigos e vagabundos. Enquanto doentes, cegos, etc., que eram os "pobres de verdade", contavam com assistência, os demais eram perseguidos.

As informações sobre a existência dos ciganos no Brasil apontam que eles ocuparam a península Ibérica nos séculos XIV e XV e migraram principalmente de Portugal. Foram deportados por determinação da Coroa Portuguesa até o final do século XVIII. Portugal, seguindo a tendência de outros países do continente europeu, adotou decretos para erradicar os ciganos ou obrigá-los a seguir as normas estabelecidas. 
No século XVII, principalmente, ocorreu o maior número de deportação de ciganos para a América Portuguesa, por conta da resolução real de 1686, um decreto que determinou a expulsão dos ciganos para outros lugares, medida utilizada para livrar o país dos indivíduos considerados como inúteis e indesejáveis.

Para Souza (2009, p.30-31), o processo de marginalização da população cigana no Brasil gerou a exclusão dos mesmos de instituições escolares, dificulta a assistência médica e outras restrições de direitos civis. O autor também afirma que a discriminação e o medo dificultavam as relações sociais positivas entre ciganos e não-ciganos.

Assim se constituiu uma trajetória marcada pela exclusão e por estereótipos negativos. Para Lima (2016, p. 3), alguns grupos são desumanizados, pois em uma escala de hierarquia que é criada eles são considerados menos humanos por não possuírem determinadas características. Essa construção de atributos desumanizadores é o elemento principal do preconceito e das relações de superioridade e medo que são construídas em relação ao outro.

\section{Questões de alteridade e outrização em “O cigano" e “A volta do cigano”}

A representação na literatura de grupos excluídos é importante para as discussões sobre as condições em que os indivíduos se encontram na sociedade, de modo a possibilitar espaço aos sujeitos, tradicionalmente ignorados ou silenciados. Desse modo, ela desafia uma tradição canônica de literatura que propaga a descriminação e os preconceitos.

Nos contos "O cigano" e "A volta do cigano" observamos a partir dos problemas colocados por Medauar no que se refere às relações do cigano com pessoas de outros grupos culturais e sociais, aspectos que podemos pensar em questões de alteridade, pois os processos de descoberta do outro se configuram de diversas formas e como explica Tzvetan Todorov (1983, p. 3):

Podem-se descobrir os outros em si mesmo, e perceber que não se é uma substância homogênea, e radicalmente diferente de tudo o 
que não é si mesmo; eu é um outro. Mas cada um dos outros é um eu também, sujeito como eu. Somente meu ponto de vista, segundo o qual todos estão lá e eu estou só aqui, pode realmente separá-los e distingui-los de mim. Posso conceber os outros como uma abstração, como uma instância da configuração psíquica de todo indivíduo, como o Outro, outro ou outrem em relação a mim. Ou então como um grupo social concreto ao qual nós não pertencemos. Este grupo, por sua vez, pode estar contido numa sociedade: as mulheres para os homens, os ricos para os pobres, os loucos para os "normais". Ou pode ser exterior a ela, uma outra sociedade que, dependendo do caso, será próxima ou longínqua: seres que em tudo se aproximam de nós, no plano cultural, moral e histórico, ou desconhecidos, estrangeiros cuja língua e costumes não compreendo, tão estrangeiros que chego a hesitar em reconhecer que pertencemos a uma mesma espécie.

Portanto, pode-se ter a compreensão de que as diferenças são inerentes aos seres humanos, todo sujeito é um outro. Os outros passam a ser distintos de nós, enquanto indivíduos, apenas se aplicadas práticas para diferenciá-los. A representação dos ciganos elaborada por Jorge Medauar é importante, primeiro porque não confere ao personagem estereótipos negativos:

Muitas vezes afirmara ao compadre que o cigano era gente de bem. Incapaz de um mal. Diferente do povo, isso era: não dava corda na língua, em conversa sem sentido. Gostava de criança e isto era uma coisa boa. Suas histórias eram para elas. Nunca que ninguém o visse batendo boca fora de propósito. A não ser com os meninos: dava a mão a eles, se acocorava com eles no chão, acompanhava a carreira das formigas, ensinava brinquedos, riscava figura de bichos na areia. Até jagunço, que era gente sem contemplação, gostava dele. Davamlhe bolos de dinheiro, para que revelasse a sorte. Lia a mão como nenhum, mas raramente. A jagunçada, como um bando de menino, pedia que contasse histórias. Contava. Ficava horas e horas entre eles, no acampamento, como um rei. Diziam até que começara a vida com um cavalo, ganho como agrado de um jagunço. A verdade mesmo ninguém podia saber. Que o homem não era de revelação (MEDAUAR, 1960, p. 130).

Ou seja, o personagem apresenta características que determinam seu caráter, não praticava o mal, solidário, respeitado pelas pessoas e gostava, em especial, das crianças, 
visto que, além de contar as histórias, dedicava-lhes atenção. Outro personagem da história, Calimério, revela para João das Neves as qualidades do cigano, já que em nenhum momento dos dois contos o próprio cigano argumenta em sua defesa. Podemos perceber o seu silêncio diante da opressão que sofria:

O homem cego, gordo de ódio. Grudava a orelha do menino com os dedos fortes, mais duros que alicate. $\mathrm{E}$ ali mesmo, no meio do povo, sacudia ofensas no cigano. Cada palavra mais cabeluda que caranguejeira. Nenhum respeito pelos meninos sem idade, pelas tabaroas presentes. O cigano, nem pio, longe dali. Seu João levando o menino espichado pelas orelhas. [...]. Sentia pena do menino, a vontade era dizer que não fizesse aquilo, perdesse o cuidado. Mas tinha que trancar a boca, esconder seus sentimentos. Então como se não tivesse acontecido nada, voltava ao ponto interrompido de sua história (MEDAUAR, 1960, p. 90).

João das Neves não aceita um pensamento contrário às normas de seu meio social, principalmente por esse outro estar em uma situação desprestigiada. O comerciante, como pertencente ao grupo que goza de mais prestígio, passa a utilizar os estigmas e estereótipos que são conferidos aos ciganos para desmoralizá-lo. De acordo com Lídia Spaziani (2016, p. 33), a estigmatização de um indivíduo ou grupo está relacionada com o juízo de valor que determinados membros de uma sociedade aplicam aos outros, assim na utilização de rótulos e estereótipos são colocados em uma condição de indivíduos ou grupos inferiores. Através dos processos de alteridade e da forma como nos enxergamos e nos colocamos no lugar do outro que levará alguns indivíduos a ignorar ou frisar esse lugar inferiorizado.

Segundo Rodrigo Teixeira (2008), alguns estudos apontam que a representação dos ciganos em documentos e no imaginário social é composta por diversos estereótipos negativos. São considerados como pessoas desonestas, preguiçosas, etc. Por não frequentarem igrejas e realizarem seus próprios rituais de matrimônio e funeral eram taxados como sujos e pagãos. As mulheres que utilizam a leitura de mãos eram chamadas de bruxas.

Em uma passagem do conto, o cigano avalia que o mesmo preconceito tinha ocorrido em outros lugares e que é difícil romper com a imagem negativa atribuída aos ciganos 
possuem: "Mas já sentia que o tempo de afastar estava chegando. Iria rarear até sumir. Recebera ofensas em outras cidades. Em qualquer parte do mundo cigano era mal visto, olhado de banda. O povo temia. E era difícil acabar com o medo do povo (MEDAUAR, 1960 , p. 90) '. Está claro na narrativa que o ódio do comerciante não foi despertado, em um primeiro momento, pela sua condição de cigano, mas ele se utilizou dos estereótipos para desumanizá-lo:

Assim que seu João abriu as portas da loja, avistou a tenda. O sangue latejou na hora, correndo esquentando pelo corpo. Seria dessa vez que o cigano faria uma desgraça, pensou. De tanto esparramar misérias, já não podia tirar da cabeça que o homem era ladrão de cavalo e de criança. Decerto viera se vingar. Viera buscar seu filho, ou o menino do gringo. Era preciso botar para longe o perigo. Teria que agir logo. Falaria com o delegado, o intendente, antes que o cigano tramasse sua vingança (MEDAUAR, 1960, p. 91).

João das Neves propagou tanto ideias negativas sobre o cigano, que ele mesmo passa a acreditar nelas e a temer sua presença na cidade. A alteridade é construída a partir das interpretações e forma como lidamos com as diferenças, e a literatura pode atuar como um lugar privilegiado para a expressão da outridade, com possibilidades de representar a questão da alteridade de forma simbólica e complexa (ALMEIDA, 2007, pp. 16-17).

Para Todorov (1983) a problemática da alteridade compreende uma discussão em diversas dimensões e podemos dividir em pelo menos três eixos. Existe o julgamento de valor, avaliamos se o outro é bom ou mal, se gostamos ou não dele, se ele é igual ou inferior. Após esse julgamento nos aproximamos ou distanciamos do outro e entra em jogo a questão dos valores, se nos identificamos com ele ou buscamos assimilá-lo impondo nossa própria imagem. Entre a submissão ao outro e a submissão do outro há ainda a questão da neutralidade ou indiferença.

O terceiro eixo diz respeito a conhecer ou ignorar a identidade do outro, neste caso, não há nenhum absoluto, de forma que não conheçemos ou ignoro o outro completamente. Existem relações e afinidades entre esses três planos; não podemos reduzi-los um 
ao outro, nem prever que um vai ocorrer a partir do outro. Nas diversas dimensões que podemos discutir a alteridade Isaías Carvalho (2003) propõe que:

[...] enquanto a alteridade é um processo que todos experimentam, em sentido psicológico e psicanalítico, os procedimentos de "outrização" têm implicações específicas quando se prestam a interditar, desautorizar, inferiorizar, demonizar, silenciar e colonizar o "outro" (p. 10).

Assim, na alteridade, ocorre uma troca a partir dos processos de reconhecimento ou não de si mesmo e do outro. Na outrização, reservam-se as práticas em que o outro é negado. O termo outrização é utilizado como tradução para othering, é um processo em que a identidade positiva de um grupo será exaltada e outro grupo, o “outro", será estigmatizado e rebaixado (CARVALHO, 2003, p.10).

Nos contos, o cigano está envolto nas diversas dimensões da alteridade e das possíveis relações entre elas. O personagem passa por julgamentos de valor, por relações de aproximação ou distanciamento e de conhecimento ou negação da identidade. Acontece também a outrização, pois é silenciado, desautorizado a continuar com o seu trabalho, e inferiorizado. Com as crianças e as pessoas que gostam de ouvi-lo, por exemplo, o cigano possui uma relação de aproximação e a outrização com João das Neves.

As narrativas demonstram a complexidade de pensarmos sobre a alteridade e como as relações com o "outro" estão condicionadas a questões culturais e socais e situações que surgem nesse processo. Não devemos deixar de considerar Jorge Medauar como um narrador de "ofício" - aquele que ocupa um lugar de prestígio, segundo Valeria De Marco (2004, p.46) - pode desenvolver um trabalho com legitimidade e dar visibilidade e voz a sujeitos subalternos e marginalizados que não tiveram espaço na "história oficial". A literatura se apresenta, portanto, um espaço para representar e discutir lacunas presentes na história oficial. 


\section{LA REPRESENTACIÓN DE LOS GITANOS EM CUENTOS DE JORGE MEDAUAR}

RESUMEN:El artículo presenta un análisis sobre la representación de los gitanos en los cuentos "O cigano" y " $A$ volta do cigano", publicados por primera vez en el libro A procissão e os porcos (1960), del escritor sur-baiano Jorge Medauar. Así, discutimos cómo el escritor destaca la presencia de los pueblos gitanos en el interior del sur de Bahía, además de abordar los aspectos de su narrativa y cuestiones de alteridad.

PALABRAS-LLAVE: Alteridad; Gitanos; Jorge Medauar; Literatura regional.

\section{REFERÊNCIAS}

ALMEIDA, Sandra Regina Goulart. Pensando o conceito de alteridade hoje. Aletria, v.16, p.13-19, jul. \dez. 2007.

BORGES, Isabel Cristina Medeiros Mattos. Cidades de portas fechadas: A intolerância contra os ciganos na organização urbana na primeira república. 2007. 131 f. Dissertação (Mestrado em História) - Universidade Federal de Juiz de Fora, Juiz de Fora, 2007.

CANDIDO, Antonio. O direito à literatura. In: Vários escritos. $3^{a}$ ed. ver. e ampl. São Paulo: Duas Cidades, 1995. p. 235-263.

CARVALHO, Isaías Francisco de. Omeros-Walcott. outrização produtiva; uma poética semiutópica dos encontros culturais. 158 f. Dissertação (Mestrado) - Instituto de Letras, Universidade Federal da Bahia, 2003.

CHIAPPINI, Ligia. Regionalismo (s) e regionalidade (s): trajetória de uma pesquisadora brasileira no diálogo com pesquisadores europeus e convite a novas aventuras. In: ARENDT, João Cláudio; NEUMANN, Gerson Roberto (Org.). Regionalismus - Regionalismos: subsídios para um novo debate. Caxias do Sul: Educs, 2013, p.13-35.

COUTINHO, Casi Ladi Reis. "Perturbadores da ordem": ciganos mero caso de polícia? Revista Tempo, Espaço, Lingaugem, v.04, n. 02, p.21-30, mai./ago. 2013.

DE MARCO, Valeria. A literatura de testemunho e a violência de estado. Lua Nova, n. 62, p. 45-68, 2004.

FRIEDMAN, Norman. O ponto de vista na ficção: o desenvolvimento de um conceito crítico. Trad. de Fábio Fonseca de Melo. Revista USP, São Paulo, n 53, mar./mai. 2012, p.166-182.

GALVÃO, Walnice Nogueira. O lugar de Guimarães Rosa na literatura brasileira. In: Guimarães Rosa. São Paulo: Publifolha, 2000, p. 13-26.

GINZBURG, Jaime. O narrador na literatura brasileira contemporânea. Tintas, Milão, n. 2, 2012, p. 199-221.

LIMA, M. E. O.; FARO, A.; SANTOS, M. R. A.; desumanização Presente nos Estereótipos de Índios e Ciganos. Psicologia: Teoria e pesquisa, Sergipe, v.32, n. 1, p.219-228, jan./mar.,2016. 
MEDAUAR, Jorge. O cigano. In: MEDAUAR, Jorge. A procissão e os porcos. São Paulo: Livraria Francisco Alves, 1960. p.79-97.

. A volta do cigano. In: MEDAUAR, Jorge. A procissão e os porcos. São Paulo: Livraria Francisco Alves, 1960. p.79-97.

MELO, Ana Amelia M. C. A revista Literatura: entre autonomia e engajamento intelectual (1946-1948). ArtCultura, Uberlândia, v. 17, n. 31, p.137-149, jul.-dez. 2015.

ODETE, Maria; MATILDE, Maria; MEDAUAR JR, Jorge (Org.). Jorge Medauar em prosa e verso. Ilhéus: Editus, 2006.

PIMENTA, Emanuel Dimas de Melo. Jorge Medauar: o homem que sabia demais. Londres: ASA Art and Technology, 2008. Disponível em: <http://www.emanuelpimenta.net/ebooks/archives/Emanuel\%20Pimenta $\% 20$ -

$\% 20$ MEDAUAR\%20BR\%202008.pdf>.

SCHMITT, Jean-Claude. A história dos marginais. In: LE GOFF, J. A história nova. 4. ed. São Paulo: Martins Fontes, 1988. p. 261-289.

SOUZA, Lídio de. et. al. Procesos identitarios entre gitanos: desde la exclusión hasta uma cultura de libertad. Revista Liberabit, p. 30-37, mai. 2009.

SPAZIANI, Lídia. A estigmatização em relação aos ciganos: as construções avaliativas por nãociganos. 2016. 228 f. Tese (Doutorado em Letras) - Universidade de São Paulo, São Paulo, 2016.

TEIXEIRA, Rodrigo Corrêa (2008). História dos ciganos no Brasil. Recife: Núcleo de Estudos Ciganos.

TODOROV, Tzvetan. A descoberta da América. In: A conquista da América: a questão do outro. Tradução de Beatriz Perrone-Moisés. São Paulo: Martins Fontes, 2003. p. 317.

. Tipologia das relações com outrem. In: - A conquista da América: a questão do outro. Tradução de Beatriz Perrone-Moisés. São Paulo: Martins Fontes, 2003. p. 269-293.

Recebido em: 14/09/2017. Aprovado em: 12/12/2017. 